\title{
DIRASAH
}

Volume 3, Number 1, Februari 2020

p-ISSN: 2615-0212 | e-ISSN: 2621-2838

https://ejournal.iaifa.ac.id/index.php/dirasah

\begin{tabular}{|c|c|c|}
\hline Accepted: & Revised: & Published: \\
Nopember 2019 & Januari 2020 & Februari 2020 \\
\hline
\end{tabular}

\section{Manajemen Interpersonal Perspektif \\ Sumberdaya Manusia, Motivasi dan Kinerja Dalam Organisasi}

\author{
Zuhri \\ Kemenag Kab. Kediri \\ e-mail:azuhriabdullah@gmail.com
}

\begin{abstract}
The study aims to analyze matters relating to performance enhancement within the organization, being reviewed from various aspects, such as; 1. Overview of MSDM, 2. Reviews on motivation, 3. Overview of the performance, 4. An overview of interpersonal skills. With focus discussion. 1what is the basic concept of human resource management in the organization, 2 how the basic concept of motivation in the organization, 3 how basic concept of performance in the organization, 4 how the concept of human resources, motivation, and performance in management Interpersonal. Types of correlational qualitative research. Data analysis techniques with the research path of 1 successful factor that determines individual performance and the team in the organization are knowledge or skill and willingness to walk together.
\end{abstract}

Keywords :Organization, performance and interpersonal management 


\section{Abstarksi}

Penelitian ini bertujuan untuk menganalisis hal-hal yang berhubungan dengan peningkatan kinerja dalam organisasi, ditinjau dari berbagai aspek, seperti; 1 . Tinjauan tentang MSDM, 2.tinjauan tentang motivasi, 3. Tinjauan tentang kinerja, 4. Tinjauan tentang keterampilan interpersonal. Dengan focus pembahasan. lbagaimana konsep dasar manajemen sumberdaya manusia dalam organisasi, 2 bagaimana konsep dasar motivasi dalam organisasi, 3 bagaimana konsep dasar kinerja dalam organisasi, 4 bagaimana konsep sumberdaya manusia, motivasi dan kinerja dalam manajemen interpersonal. Jenis penelitian kualitatif korelasional. Teknik analisis data dengan jalur hasil penelitian 1 faktor sukses penentu kinerja individu maupun tim dalam organisasi adalah pengetahuan atau keterampilan dan kemauan berjalan secara bersama sama.

Keywords: organisasi, kinerja dan manajemen interpersonal

\section{Pendahuluan}

Mengelola lembaga pendidikan berarti melakukan proses penataan kelembagaan pendidikan yang melibatkan sumberdaya manusia dan non manusia dalam menggerakkannya untuk mencapai tujuan pendidikan secara efektif dan efisien. ${ }^{1}$ Pendidikan yang berkualitas atau bermutu akan tercapai, apabila didukung oleh seluruh komponen pendidikan yang terorganisir dengan baik. Keterorganisiran ini mensyaratkan adanya kepemimpinan yang baik dari para pemimpin pendidikan.

Kepemimpinan merupakan seni memotivasi atau menginspirasi sekelompok orang untuk bertindak dalam mencapai tujuan bersama. Seorang pemimpin adalah orang dalam kelompok yang memiliki kombinasi kepribadian dan ketrampilan yang membuat orang lain ingin mengikuti arah mereka. ${ }^{2}$ Menurut Kreitner (dalam Muhtarom), kepemimpinan (leadership) merupakan proses mempengaruhi orang, dimana pemimpin mengusahakan keikutsertaan bawahan yang dengan hasrat dan kemauan sendiri berusaha untuk mencapai tujuan organisasi. ${ }^{3}$ Sedangkan menurut Tannenbaum, Wesler dan Massarik (dalam Wahyusumidjo) adalah kemampuan seseorang dalam mempengaruhi orang lain dengan sengaja, dalam situasi melalui proses komunikasi untuk mencapai tujuan atau tujuan-tujuan tertentu. ${ }^{4}$ Adapun

\footnotetext{
${ }^{1}$ Prim Masrokan Mutohar, Manajemen Mutu Sekolah; Strategi Mutu Dan Daya Saing Lembaga Pendidikan Islam, cet 2, (Yogyakarta, Ar-Ruzz media, 2014), 37.

${ }^{2}$ Sutarno, Serba-serbi Manajemen Bisnis, (Graha Ilmu, Yogyakarta 2011), 80

${ }^{3}$ Zaini Muchtarom, Dasar-Dasar Manajemen Dakwa, (Yogyakarta: Al-Amin Press, 1996), 74.

${ }^{4}$ Wahyusumidjo, Kepemimpinan Kepala Sekolah, Tinjauan Teoritik dan Permasalahan (Jakarta; Raja Grafindo Persada, 2002), 17.
}

Dirasah, Vol. 3, No. 1, Februari 2020 
menurut Ivacevich, kepemimpinan adalah suatu upaya penggunaan jenis pengaruh bukan paksaan untuk memotivasi orang-orang mencapai tujuan tertentu. ${ }^{5}$

Berkaitan dengan kepemimpinan pendidikan, Pathoni menyatakan bahwa kepemimpinan pendidikan merupakan suatu proses mempengaruhi, mengkoordinir, dan menggerakkan orang lain yang ada hubungan dengan pengembangan ilmu pendidikan dan pelaksanaan pendidikan dan pembelajaran agar kegiatan-kegiatan yang dijalankan dapat lebih efisien dan efektif demi mencapai tujuan-tujuan pendidikan dan pembelajaran. Kepemimpinan pendidikan juga dapat diartikan sebagai proses kegiatan usaha mempengaruhi, menggerakkan, dan mengkoordinasikan personal di lingkungan pendidikan pada situasi tertentu agar mereka melalui kerjasama mau bekerja dengan penuh tanggung jawab dan ikhlas demi tercapainya tujuan pendidikan yang telah dirumuskan. ${ }^{6}$

Berbagai pengertian tentang pengelolaan (managership) dan kepemimpinan (leadership) di atas mengisyaratkan bahwa kegiatan kepemimpinan dan manajemen berkaitan dengan seluruh anggota organisasi sebagai sumberdaya manusia (menggerakkan dan mengkoordinasikan), motif-motif anggota organisasi (menggerakkan dan mempengaruhi) dan kinerja anggota. Maka kemampuan kepemimpinan atau manajerial pendidikan dalam hal ini mensyaratkan adanya kemampuan pemimpin atau manajer dalam mengelola sumberdaya manusia, motivasi anggota (bawahan) dan pada akhirnya kinerja anggota organisasi.

Menurut Husaini Usman, peranan yang dimainkan oleh setiap manajer dan leader antara lain adalah berhubungan dengan orang lain. Untuk itu ia harus memiliki ketrampilan interpersonal atau social, disamping ketrampilan konseptual dan operasional. ${ }^{7}$ Paul Hersey menyatakan bahwa dalam rangka pelaksanaan tugastugas manjerial paling tidak diperlukan tiga macam bidang keterampilan, yaitu technical, human, dan conceptual. ${ }^{8}$ Robbins juga mengemukakan bahwa "Tugas manajerial paling tidlak diperlukan tiga macam bidang keterampilan yaitu : keterampilan konseptual, keterampilan manusiawi dan keterampilan teknis. ${ }^{9}$

\footnotetext{
${ }^{5}$ Ivanchevich, John. M. Donelly Jr, James H. Gibson, Organisasi, (Suarabay; Erlangga, 1995), 334.

${ }^{6}$ Achmad Patoni, Konsep Dasar Kepemimpinan Profetik Pendidikan Islam (Tulungagung, IAIN Tulungagung, 2017), 95.

${ }^{7}$ Husaini Usman, Manajemen; Teori Praktik dan Riset Pendidikan, (Yogyakarta, Pustaka Pelajar, 2014), 517.

${ }^{8}$ Paul Hersev, Paull Hersey and Ken Blanchard, Majemen Perilaku Organisasi : Pendayagunaan Sumber Daya Manusia, terj. (Jakarta: Erlangga, 1982), 6-7

${ }^{9}$ Robbins P. Stepter, Perilaku Organisasi (Jakarta: Gramedia, 2003), 7
}

Dirasah, Vol. 3, No. 1, Februari 2020 
Conceptual skill adalah ketrampilan manajerial yang meliputi kemampuan analisis, kemampuan berpikir, rasional, kemampuan dalam berbagai macam konsepsi, kemampuan dalam menganalisis berbagai kejadian, kemampuan dalam memahami berbagai kecenderungan, kemampuan dalam mengantisipasi perintah dan kemampuan mengenali macam-macam kesempatan dan problem-proplem social. Technical Skill adalah ketrampilan manajerial yang meliputi kemampuan dalam menguasai pengetahuan tentang metode, proses, prosedur dan teknik untuk melaksanakan kegiatan khusus dan kemampuan untuk memanfaatkan serta mendayagunakan sarana, peralatan yang diperlukan dalam mendukung kegiatan yang bersifat khusus. Sementara human skill adalah ketrampilan manajerial yang meliputi kemampuan untuk memahami perilaku manusia dan proses kerja sama, kemampuan untuk memahami isi hati, sikap dan motif orang lain, mengapa mereka berkata dan berperilaku, kemampuan untuk berkomunikasi secara jelas dan efektif, kemampuan menciptakan kerja sama yang efektif, kooperatif, praktis dan diplomatic dan kemampuan dalam berperilaku yang dapat diterima. ${ }^{10}$

\section{Tinjauan tentang Manajemen Sumberdaya Manusia \\ Pengertian Manajemen Sumberdaya Manusia}

Menurut Deconzo dan Robbins (dalam Riyadi), manajemen sumber daya manusia adalah suatu proses yang terdiri atas suatu penerimaan, pengembangan motivasi, dan pemeliharaan sumber daya manusia. Menurut Marwansyah (dalam Riyadi), manajeman sumber daya manusia dapat diartikan sebagai pendayagunaan sumber daya manusia di dalam organisasi, yang dilakukan melalui fungsi-fungsi perencanaan sumber daya manusia, rekrutmen dan seleksi, pengembangan sumber daya manusia, perencanaan dan pengembangan karir, pemberian kompensasi dan kesejahteraan, keselamatan, kesehatan kerja, dan hubungan industrial". ${ }^{11}$ sedangkan menurut Desler, manajemen sumber daya manusia adalah proses memperoleh, melatih, menilai, dan memberikan kompensasi kepada karyawan, memerhatikan hubungan kerja mereka, kesehatan, keamanan dan masalah keadilan. ${ }^{12}$

Berdasarkan definisi di atas maka dapat diperoleh kejelasan bahwa manajemen sumber daya manusia adalah kegiatan yang berhubungan dengan perencanaan, pengorganisasian, pengarahan, dan pengawasan dengan suatu

\footnotetext{
${ }^{10}$ Wahjosumidjo,Kepemimpinan Kepala Sekolah, (Jakarta, Raja Grafindo Persada, 2003), 101-102

${ }^{11}$ Abdurokhim Agus Riyadi, Pengaruh Motivasi Kerja Konsep Islami Terhadap Kinerja Pegawai, Amwaluna, Vol. 1 No.2 (Juli, 2017), 246-262

${ }^{12}$ Gary Dessler, Manajemen Sumberdaya Manusia, (Jakarta, Indeks, 2918), edisi 10, jilid 1, 5.
}

Dirasah, Vol. 3, No. 1, Februari 2020 
motivasi terhadap pelaksanaan untuk mendapatkan, mengembangkan, kompensasi, memelihara integrasi, organisasi, dan masyarakat dapat tercapai selektif dan seefisien mungkin.

Dalam konteks pendidikan, sumber daya manusia meliputi kepala sekolah, guru, pegawai tata usaha, siswa, BP3, pengawas, dan aparat dinas pendidikan. ${ }^{13}$ Namun dalam praktiknya, dalam lembaga pendidikan lebih identic dengan manajemen personalia dibandingkan manajemen sumber daya manusia.

\section{Konsep dasar manajemen sumber daya manusia}

Sebagai bagian dari manajemen, manajemen sumber daya manusia pada dasarnya merupakan penerapan fungsi-fungsi manajemen dalam konteks pengelolaan sumber daya manusia. Adapun fungsi-fungsi manajemen sumber daya manusia tersebut adalah;

1) Perencanaan pegawai. Perencanaan pegawai ini merupakan kegiatan untuk menentukan kebutuhan pegawai, baik secara kuantitatif, maupun kualitatif, untuk masa sekarang dan masa depan. Penyusunan rencana personalia yang baik dan tepat memerlukan informasi yang lengkap dan jelas tentang tugas atau pekerjaan yang harus dilakukan dalam organisasi. ${ }^{14}$

2) Pengadaan pegawai. Pengadaan pegawai merupakan suatu usaha untuk memperoleh jenis dan jumlah yang tepat dari personalia yang diperlukan untuk menyelesaikan sasaran organisasi. Usaha ini dilakukan untuk mengisi jabatan-jabatan tertentu yang masih kosong, baik akibat pembentukan unit baru yang menyebabkan timbulnya kegiatan yang membutuhkan pelaksanapelaksana, maupun sebagai akibat terjadinya mutasi atau penggantian pegawai sehingga kemudian dibutuhkan pegawai baru atau pergantian posisi. $^{15}$

3) Pembinaan dan pengembangan pegawai. Pengembangan merupakan peningkatan ketrampilan melalui pelatihan yang perlu untuk prestasi kerja yang tepat. Meskipun seorang pegawai telah memiliki bekal pengetahuan serta ketrampilan sebagai "preservice training" namun demi efektivitas dan efisiensi serta peningkatan produktivitas kerjanya maka kemampuan serta ketrampilannya perlu terus dikembangkan dan ditingkatkan melalui "in

\footnotetext{
${ }^{13}$ Husaini Usman, Manajemen.., 489

${ }^{14}$ E. Mulyasa, Manajemen Berbasis Sekolah, (Bandung: Remaja Rosda Karya, 2002), 43.

15 Piet A. Sahertian, Dimensi-Dimensi Administrasi Pendidikan di Sekolah (Surabaya, Usaha Nasional: 1994), 163
} 
service training." ${ }^{16}$ In service training ialah segala kegiatan yang diberikan dan diterima oleh para petugas pendidikan (pengawas, kepala sekolah, penilik sekolah, guru dan sebagainya) yang bertujuan untuk menambah dan mempertinggi mutu pengetahuan, kecakapan dan pengalaman guru-guru dalam menjalankan tugas kewajibannya. ${ }^{17}$ Tujuan dari pengembangan dan pembinaan adalah; meningkatkan kuantitas output, meningkatkan kualitas output, merealisasikan perencanaan personalia, meningkatkan moral kerja, meningkatkan penghasilan atau kesejahteraan, meningkatak kesehatan dan keamanan, mencegah ketuaan, untuk mengembangkan personalia itu sendiri. $^{18}$

4) Promosi, mutasi dan pemberhentian pegawai. Sebelum dilakukan promosi, mutasi ataupun pemberhentian pegawai harus diadakan penilaian terlebih dahulu terhadap para pegawai atau para personalia. Yang dimaksud dengan penilaian pegawai adalah usaha-usaha yang dilakukan untuk mengetahui secara formal maupun informal hal-hal yang menyangkut pribadi, status, pekerjaan, prestasi kerja maupun perkembangan pegawai. ${ }^{19}$

5) Kompensasi. Kompensasi adalah balas jasa yang diberikan organisasi kepada pegawai, yang dapat dinilai dengan uang dan mempunyai kecenderungan diberikan secara tetap. ${ }^{20}$

6) Evaluasi. Untuk melaksanakan fungsi-fungsi yang dikemukakan terdahulu, diperlukan sistem evaluasi atau penilaian pegawai secara obyektif dan akurat. Penilaian tenaga kependidikan ini difokuskan pada prestasi individu dan peran sertanya dalam kegiatan sekolah. ${ }^{21}$

\section{Tinjauan tentang Motivasi}

\section{Pengertian motivasi}

Motivasi dapat diartikan sebagai keadaan kejiwaan dan sikap mental manusia yang memberikan energi mendorong kegiatan (moves) dan mengarah atau menyalurkan perilaku kearah mencapai kebutuhan yang memberikan kepuasan atau mengurangi ketidakseimbangan. Menurut Robbins \& Coulter, motivasi adalah kesediaan melakukan usaha tingkat tinggi untuk mencapai

16 Ary Gunawan, Administrasi Sekolah, Administrasi Pendidikan Mikro, (Jakarta: Rineka Cipta, 1996), 62.

${ }^{17}$ Ngalim Purwanto dan Sutaadji Djojopranoto, Administrasi Pendidikan, (Jakarta: Mutiara Sumber Widya, 1996), 68.

${ }^{18}$ Made Pidarta, Manajemen Pendidikan ...123.

${ }^{19}$ Piet A. Sahertian, Dimensi-Dimensi .., 169.

${ }^{20}$ E. Mulyasa, Manajemen Berbasis Sekolah .., 45

${ }^{21}$ E. Mulyasa, Manajemen Berbasis Sekolah .., 45

Dirasah, Vol. 3, No. 1, Februari 2020 
sasaran organisasi, yang dikondisikan oleh kemampuan usaha tersebut untuk memuaskan kebutuhan sejumlah individu. ${ }^{22}$

Motivasi adalah serangkaian sikap dan nilai-nilai yang mempengaruhi individu untuk mencapai hal yang spesifik sesuai dengan tujuan individu. Sikap dan nilai tersebut merupakan sesuatu yang invisible yang memberikan kekuatan yang mendorong individu untuk bertingkah laku dalam mencapai tujuan. Dorongan tersebut terdiri dari dua komponen, yaitu arah perilaku kerja (kerja untuk mencapai tujuan) dan kekuatan prilaku (seberapa kuat usaha individu dalam bekerja). ${ }^{23}$ Motivasi dapat diartikan sebagai kekuatan (energi) seseorang yang dapat menimbulkan tingkat persistensi dan antusiasmennya dalam melaksanakan suatu kegiatan, baik yang bersumber dari dalam diri individu itu sendiri (motivasi intrinsik) maupun dari luar individu (motivasi ekstrinsik). ${ }^{24}$

Berdasarkan berbagai definisi di atas dapat disimpulkan bahwa motivasi adalah sesuatu yang menjadi pendorong bagi individu untuk melakukan tindakan, baik bersifat pasif maupun aktif.

\section{Konsep dasar motivasi}

Konsep dasar dari motivasi adalah berbagai alasan yang menjadi alasan (motif) dalam melakukan sesuatu. Sejumlah ahli kemudian mengembangkan berbagai teori motivasi, seperti;

Teori Hirerki kebutuhan Abraham Maslow. Menurut Maslow, pada diri setiap orang terdapat hirarki lima kebutuhan, yaitu; 1) Kebutuhan fisiologikal (physiological needs); 2) Kebutuhan rasa aman (safety needs), tidak dalam arti fisik semata, akan tetapi juga mental, psikologikal dan intelektual; 3) Kebutuhan social; 4) Kebutuhan akan harga diri (esteem needs); 5) Aktualisasi diri (self actualization $).{ }^{25}$ Tiap tingkat dalam hirarki tersebut harus secara substansial terpuaskan sebelum hirarki berikutnya aktif.

1) Teori $X$ dan Y Doughlas McGregor. Pada dasarnya terdapat dua kelompok sifat manusia, $\mathrm{X}$ dan $\mathrm{Y}$. Teori $\mathrm{X}$ diasumsikan bahwa para pekerja mempunyai sedikit ambisi untuk maju, tidak menyukai pekerjaan, ingin menghindari tanggung jawab dan perlu diawasi secara ketat agar dapat bekerja efektif.

\footnotetext{
${ }^{22}$ Stephen P Robbins \& Mary Coulter, Manajemen, edisi ke 8, jilid 2, (Yogyakarta, Indeks, 2007), 129.

${ }^{23}$ Veithzal Rivai, Ella Jauvani Sagala, Managemen Sumber Daya Manusia untuk Perusahaan, (Jakarta; Rajawali Pers, 2013), 837

${ }^{24}$ Purnamie Titisari, Peranan Organizational Citizenship Behavior (OCB) Dalam Meningkatkan Kinerja Karyawan, (Jakarta; Mitra Wacana Media, 2014), 27

${ }^{25}$ Purnamie Titisari, Peranan Organisasi.., 31
}

Dirasah, Vol. 3, No. 1, Februari 2020 
Teori Y berasumsi bahwa para pekerja dapat berlatih mengarahkan diri, menerima dan secara nyata mencari tanggung jawab dan mengganggap bekerja sebagai kegiatan alami. McGregor berpendapat bahwa partisipasi dalam pengambilan keputusan, pekerjaan yang menuntut tanggung jawab dan menantang, dan hubungan kelompok yang baik akan memaksimalkan motivasi karyawan. ${ }^{26}$

2) Teori Higienis Frederick Herzberg. Teori ini mengatakan ada 2 faktor yang mempengaruhi seseorang dalam bertugas pekerjaanya yaitu; 1) faktor intrinsic; seperti prestasi, penghargaan, penghargaan, tanggung jawab, kesempatan untuk maju, pekerjaan itu sendiri; dan 2) ektrinsik, seperti kondisi kerja, hubungan interpersonal, kebijakan dan administrasi perusahaan, pengawasan, gaji, keamanan kerja. ${ }^{27}$

3) Teori tiga kebutuhan David McClelland, bahwa ada tiga kebutuhan yang menjadi motif utama dalam pekerjaan, yaitu kebutuhan akan pencapaian prestasi (need for achievement; nAch), kebutuhan akan kekuasaan (need for power; nPow), dan kebutuhan akan afiliasi (need for affiliation). ${ }^{28}$

4) Teori penentuan sasaran, bahwa niat bekerja mencapai sasaran merupakan sumber utama motivasi kerja. Factor hubungan sasaran dan kinerja ini dipengaruhi oleh factor komitmen pada sasaran, kemampuan diri yang memadai dan budaya nasional. ${ }^{29}$.

5) Teori penguatan (B.F. Skinner); bahwa orang cenderung melakukan perilaku yang dikehendaki jika mereka mendapat imbalan untuk berbuat begitu; imbalan tersebut akan sangat efektif jika segera diberikan menyusul perilaku yang diinginkan; dan perilaku yang tidak diberi imbalan, atau yang dihukum, kurang cenderung diulang. ${ }^{30}$.

6) Teori model karakteristik pekerjaan (JCM), bahwa dimensi pekerjaan inti (ragam ketrampilan, identitas tugas, kepentingan tugas, otonomi dan umpan balik) berdampak pada psikologis yang menentukan (pengalaman akan arti bekerja, pengalaman akan tanggung jawab atas hasil kerja, dan pengetahuan akan hasil sesungguhnya dari kegiatan bekerja) yang menentukan hasil pribadi dan hasil kerja (motivasi kerja dari dalam yang tinggi, kinerja yang berkualitas tinggi, kepuasan kerja yang tinggi dan absensi dan perpindahan

\footnotetext{
${ }^{26}$ Stephen P Robbins \& Mary Coulter, Manajemen ..., 132.

${ }^{27}$ Purnamie Titisari, Peranan Organisasi.., 37.

${ }^{28}$ Stephen P Robbins \& Mary Coulter, Manajemen.., 135

${ }^{29}$ Ibid, 139.

${ }^{30}$ Ibid, 140
}

Dirasah, Vol. 3, No. 1, Februari 2020 
yang rendah). Dalam konteks motivasi, JCM mengemukakan bahwa imbalan instrinsik (internal) diperoleh ketika karyawan belajar (pengetahuan hasil dari umpan balik) bahwa secara pribadi dia (merasa bertanggung jawab melalui otonomi kerja) telah bekerja dengan baik dalam tugas yang dianggapnya penting (mengalami makna melalui keragaman ketrampilan, identitas tugas, dan signifikansi tugas). Jika ketiga kondisi ini menjadi ciri pekerjaan, maka semakin besar motivasi, kinerja dan kepuasan karyawan, dan semakin rendah ketidak hadiran dan kecenderungannya mengundurkan diri. ${ }^{31}$

7) Teori kesetaraan (J. Stacey Adams), bahwa para karyawan melihat (mempersepsikan) apa yang mereka peroleh dari situasi (hasil) pekerjaan untuk dikaitkan dengan apa yang mereka masukkan ke pekerjaan itu (input), kemudian membandingkan rasio input-ouput mereka dengan rasio inputouput orang lain yang relevan. Bahwa karyawan dapat; 1) mengubah input mauput output mereka sendiri atau orang lain, 2) berperilaku sedemikian rupa untuk mendorong orang lain mengubah input atau output mereka, 3) berperilaku sedemikian rupa untuk mengubah input-output mereka sendiri, 4) memilih orang yang berbeda-beda sebagai pembanding, atau 5) meninggalkan pekerjaan mereka. ${ }^{32}$

8) Teori pengharapan (Victor Vrom), bahwa individu cenderung bertindak dengan cara tertentu berdasarkan pengharapan bahwa tindakan tersebut akan diikuti oleh hasil tertentu dan oleh daya tarik hasil tersebut bagi orang itu. Teori ini mencakup tiga variable; 1) Pengharapan atau kaitan usaha-kinerja, yaitu kemungkinan yang dirasakan untuk melakukan sejumlah usaha tertentu yang menghasilkan kinerja tertentu; 2) instrumentalis atau kaitan kinerjaimbalan, yaitu tingkat sejauh mana orang tersebut percaya bahwa bekerja pada tingkat tertentu menjadi sarana untuk tercapainya hasil yang diinginkan; 3) valensi atau daya tarik imbalan, yaitu bobot yang ditempatkan oleh orang tersebut ke potensi hasil atau imbalan yang dapat dicapai ditempat kerja, yang mempertimbangkan sasaran dan kebutuhan orang tersebut. ${ }^{33}$

9) Teori gabungan (Robinson \& Coulter). Keenam teori motivasi kontemporer bersifat saling melengkapi dan memiliki kecocokan, mempelajarinya secara terpisah adalah salah. Robinson \& Coulter kemudian menawarkan model penggabungan teori tersebut dengan meletakkan teori pengharapan sebagai

${ }^{31}$ Ibid, $144-145$

${ }^{32}$ Ibid, $146-147$

${ }^{33}$ Ibid, $148-149$

Dirasah, Vol. 3, No. 1, Februari 2020 
fondasi dasar dengan mempertimbangkan kebutuhan akan prestasi, teori penguatan, teori kesetaraan dan teori JCM; ${ }^{34}$ Teori pengharapan meramalkan bahwa karyawan akan mengeluarkan tingkat usaha yang tinggi jika mereka merasakan ada hubungan yang kuat antara usaha dan kinerja, kinerja dan imbalan, serta imbalan dan pemenuhan sasaran pribadi. Tingkat kinerja pribadi tidak hanya ditentukan oleh tingkat usaha pribadi, melainkan juga dipengaruhi oleh kemampuan orang tersebut dalam bekerja, system evaluasi kinerja organisasi (baik dan obyektif atau tidak). Hubungan kinerja-imbalan akan menjadi kuat seandainya individu itu melihat bahwa kinerjanya (bukan senioritas, anak mas, atau kriteria tertentu lainnya) yang mendapatkan imbalan.Imbalan-sasaran, motivasi akan tinggi jika sejauh imbalan yang dicapai seseorang bagi atas kinerjanya yang tinggi itu memuaskan kebutuhan dominan sesuai dengan sasaran pribadi.

\section{Tinjauan tentang Kinerja}

\section{Pengertian kinerja}

Menurut Mangkunegara kinerja atau prestasi kerja adalah sebagai hasil kerja orang secara kualitas dan kuantitas yang dicapai oleh seorang karyawan dalam melaksanakan tugasnya sesuai dengan tanggung jawabnya yang diberikan kepadanya dalam suatu kurun waktu yang ditetapkan. ${ }^{35}$ Definisi lain, menjelaskan bahwa kinerja merupakan catatan yang dihasilkan dari fungsi pegawai atau kegiatan yang dilakukan pegawai selama periode waktu tertentu. ${ }^{36}$

Kinerja (performance) dapat diartikan sebagai hasil kerja yang dapat dicapai oleh seseorang atau sekelompok orang dalam organisasi, sesuai wewenang dan tanggung jawab masing-masing, dalam rangka mencapai tujuan organisasi bersangkuatan secara legal, tidak melanggar hukum dan sesuai dengan moral maupun etika. ${ }^{37}$ Prestasi kerja adalah kemampuan seseorang dalam usaha mencapai hasil kerja yang yang lebih baik/lebih menonjol kearah tercapainya tujuan organisasi. ${ }^{38}$ Dapat disimpulkan bahwa kinerja merupakan capaian kerja.

\section{Konsep dasar kinerja}

\footnotetext{
${ }^{34}$ Ibid, $150-151$

${ }^{35}$ Ibid

${ }^{36}$ Ambar Teguh dan Rosidah, Manajemen Sumber Daya Manusia, (Yogyakarta; Graha Ilmu, 2003), 223.

${ }^{37}$ Suryadi Prawirosentono, Kebijakan Kinerja Karyawan, (Yogyakarta; BPFE, 1999), 1-2

${ }^{38}$ Purname Titisari, Peranan Organisasi..., 74
}

Dirasah, Vol. 3, No. 1, Februari 2020 
Capaian prestasi atau kinerja pada dasarnya dipengaruhi oleh berbagai factor, baik bersumber dari pribadi pekerja itu sendiri, sarana prasarana kerja, kepemimpinan, lingkungan kerja dan lain sebagainya. Secara lebih sepsifik, Kashmir mengemukakan adanya 13 faktor yang mempengaruhi kinerja seseorang, yaitu; ${ }^{39}$

1) Kemampuan dan Keahlian, yatu kemampuan atau skill yang dimiliki seseorang dalam melakukan suatu pekerjaan.

2) Pengetahuan tentang pekerjaan, bahwa seseorang yang memiliki pengetahuan tentang pekerjaan secara baik akan memberikan hasil pekerjaan yang baik, demikian pula sebaliknya.

3) Rancangan Kerja, yaitu rancangan pekerjaan yang akan memudahkan karyawan dalam mencapai tujuannya.

4) Kepribadian, bahwa setiap orang memiliki kepribadian atau karakter yang berbeda satu sama lainnya.

5) Motivasi Kerja, yaitu dorongan seseorang untuk melakukan pekerjaan. Jika karyawan memiliki dorongan yang kuat dari dalam dirinya atau dorongan dari luar dirinya (misalnya dari pihak perusahaan), maka karyawan akan terdorong melakukan sesuatu dengan baik.

6) Kepemimpinan, yaitu perilaku seseorang pemimpin dalam mengatur, mengelola, dan memerintah bawahannya untuk mengerjakan sesuatu tugas dan tanggung jawab yang diberikannya.

7) Gaya Kepemimpinan, yaitu sikap seorang pemimpin dalam menghadapi atau memerintahkan bawahannya.

8) Budaya Organisasi, yaitu kebiasaan-kebiasaan atau norma-norma yang berlaku dan dimiliki oleh suatu organisasi atau perusahaan.

9) Kepuasan Kerja, yaitu kepuasan senang atau gembira atau perasaan suka seseorang sebelum atau sesudah melakukan suatu pekerjaan.

10) Lingkungan Kerja, yaitu suasana atau kondisi di sekitar lokasi tempat bekerja.

11) Loyalitas, yaitu kesetian karyawan untuk tetap bekerja dan membela perusahaan dimana tempatnya bekerja.

12) Komitmen, yaitu kepatuhan karyawan untuk menjalankan kebijakan atau peraturan perusahaan dalam bekerja. $\mathrm{K}$

39 Kasmir, Manajemen Sumber Daya Manusia (Teori dan Praktik), (Jakarta; Raja Wali, Jakarta, 2016), 189 
13) Disiplin kerja, yaitu usaha karyawan untuk menjalankan aktifitas kerjanya secara sungguh-sungguh baik dari segi waktu, tehnis, prosedur dan lain sebagainya.

Bagi perusahaan penilaian kinerja memiliki beberapa tujuan antara lain yaitu: ${ }^{40}$ 1) Untuk memperbaiki kualitas pekerjaan; 2) Keputusan penempatan; 3) Perencanaan dan pengembangan karier; 4) Kebutuhan latihan dan pengembangan; 5) Penyesuaiaan kompensasi; 6) Inventori kompetensi pegawai;

7) Komunikasi efektif antara atasan dan bawahan; 8) Budaya kerja (penilaian kinerja akan menciptakan budaya kualitas kerja); 9) Menerapakan sanksi.

Sedangkan untuk mengukur sejauh mana kinerja seseorang (individu), menurut John Bernadin (dikutip Anwar Prabu Mangkunegara) ada empat karakteristik yang digunakan, yaitu; ${ }^{41}$

Kualitas yaitu tingkat dimana hasil aktivitas yang dilakukan mendekati sempurna dalam arti menyesuaikan beberapa cara ideal dari penampilan aktivitas ataupun memenuhi tujuan yang diharapkan suatu aktivitas.

1) Kuantitas yaitu banyaknya jumlah atau hasil pekerjaan yang dapat diselesaikan pada waktu yang telah ditentukan.

2) Ketepatan waktu yaitu tingkat suatu aktifitas diselesaikan pada waktu awal yang diinginkan, dilihat dari sudut koordinasi dengan hasil output serta memaksimalkan waktu yang tersedia untuk aktivitas yang lain.

3) Efektivitas yaitu tingkat penggunaan sumber daya organisasi dimaksimalkan dengan maksud meningkatkan keuntungan atau mengurangi kerugian dari setiap unit dalam penggunaan sumber daya.

4) Kemandirian yaitu tingkat dimana seorang karyawan dapat melakukan fungsi kerjanya tanpa meminta bantuan bimbingan dari pengawas atau meminta informasi pengawas guna menghindari hasil yang merugi

\section{Tinjauan tentang Ketrampilan Interpersonal}

\section{Pengertian ketrampilan interpersonal}

Keterampilan interpersonal adalah kecakapan yang harus dibawa individu dalam melakukan interaksi individu lain atau sekelompok individu. Johson menyatakan bahwa keterampilan interpersonal adalah jumlah keseluruhan dari kemampuan seseorang untuk berinteraksi secara efektif dengan orang lain, yaitu kemampuan untuk memulai, mengembangkan dan memelihara hubungan yang

\footnotetext{
${ }^{40} \mathrm{Ibid}, 180$

${ }^{41}$ Fuad Mas'ud, Survai Diagnosis Organisasional (Konsep dan Aplikasi), (Semarang; Badan Penerbit Universitas Diponegoro), 19
}

Dirasah, Vol. 3, No. 1, Februari 2020 
penuh perhatian dan produktif. ${ }^{42}$ Menurut Rose dan Nicholl (dalam Khilmiyah) keterampilan interpersonal adalah kemampuan bekerja secara efektif dengan orang lain, memperhatikan empati dan pengertian, memperhatikan motivasi dan tujuan mereka". ${ }^{43}$ Sementara menurut Yukl (dalam Usman) adalah kemampuan mengetahui dan melaksanakan perilaku manusia dan proses interpersonal, mampu memahami perasaan orang lain, sikap-sikap dan motifmotif yang tersurat maupun tersirat dari orang lain berupa empati dan kepekaan social, mampu berkomunikasi dengan jelas dan efektif (banyak pendapat yang bagus dan persuasive), mampu mengembangkan hubungan kerjasama yang efektif (seni bergaul, diplomasi, ketrampilan mendengarkan, pengetahuan tentang perilaku sosal yang dapat diterima orang lain). ${ }^{44}$

Berdasar definisi di atas dapat disimpulkan bahwa ketrampilan interpersonal berkaitan erat dengan kemampuan bekerja bersama orang lain dan kemampuan memperthatikan motivasi dan tujuan orang lain.

\section{Konsep dasar ketrampilan interpersonal dalam manajemen}

Seorang leader atau manajer dalam menjalankan fungsi pengarahan, harus memiliki hubungan manusiawi (human relations) sehingga mampu memahami perasaan agar pengarahan efektif dan efisien. Ketrampilan interpersonal sangat penting untuk mempengaruhi orang lain.

Menurut Johnson, proses keterampilan interpersonal umumnya terdiri dari 4 hal, diantaranya $:{ }^{45}$

1) Saling mengenal dan mempercayai. Seseorang dapat saling mengenal jika mereka saling ada keterbukaan, keterbukaan ini tergantung pada kesadaran diri dan penerimaan diri. Reaksi orang lain positif maka kepercayaan akan timbul, tetapi jika reaksi orang lain negatif maka kepercayaan hilang.

2) Saling berkomunikasi secara tepat dan jelas. Keterampilan berkomunikasi mulai dengan mengirimkan pesan sehingga orang lain dapat mengerti dengan mudah. Hal ini termasuk juga keterampilan mendengarkan yang memastikan seseorang mengerti maksud orang lain dengan benar.

42 DW. Johson. Reaching out : interpersonal effectiveness and self-actualization Englewood Cliffs, (N.J: Prentice-Hall, 1972). 54

43 Akif Khilmiyah, Perbandingan Keterampilan Intrapersonal Dan Interpersonal Berbasis Pendidikan Karakter Siswa Sekolah Dasar Negeri Kasihan Bantul, UMY, Jurnal Ilmu-Ilmu Keislaman, 2013, 55.

${ }^{44}$ Husaini Usman, Manajemen..., 520-521.

${ }^{45}$ Johson D. W. Reaching out : interpersonal effectiveness and self-actualization Englewood Cliffs, (N.J: Prentice-Hall, 1972), 61 
3) Saling menerima dan mendukung. Memberikan respon dan perhatian pada masalah orang lain serta mengkomunikasikan penerimaan dan dukungan secara tepat adalah hal yang penting dalam keterampilan berhubungan dengan orang lain.

4) Menyelesaikan konflik dan masalah dalam berhubungan dengan orang lain secara konstruktif. Konflik dapat timbul dalam interaksi antara 2 orang atau lebih. Penyelasaian terhadap konflik tergantung pada aspek kesadaran antara strategi yang digunakan untuk mengatasi konflik paradigma terhadap konflik yang dapat membawa pada penyelesaian yang kontruktif dan kemampuan merundingkan penyelesaian yang kontruktif dankemampuan merundingkan penyelesaian yang membawa keuntungan bagi kedua belah pihak.

Sementara menurut Yukl (dalam Usman) adalah kemampuan mengetahui dan melaksanakan perilaku manusia dan proses interpersonal, mampu memahami perasaan orang lain, sikap-sikap dan motif-motif yang tersurat maupun tersirat dari orang lain berupa empati dan kepekaan social, mampu berkomunikasi dengan jelas dan efektif (banyak pendapat yang bagus dan persuasive), mampu mengembangkan hubungan kerjasama yang efektif (seni bergaul, diplomasi, ketrampilan mendengarkan, pengetahuan tentang perilaku sosal yang dapat diterima orang lain). ${ }^{46}$

Arti pentingnya ketrampilan interpersonal bagi seorang manajer atau leader di antaranya adalah;

1) Dapat meningkatkan keefektifan perilaku yang berorientasi pada hubungan manusiawi (human relation).

2) Membantu leader atau manajer dalam menjadi pendengar yang baik dan tidak menyudutkan orang lain dalam masalah pribadi.

3) Membantu menentukan cara efektif dalam menyelesaikan konflik. ${ }^{47}$

Adapun prinsip-prinsip dalam dalam hubungan interpersonal adalah; a) Menjadi pribadi yang ramah, b) menjadi pribadi yang memperhatikan dan menghargai orang lain, c) menjadi pendengar yang baik, d) menjadi pribadi yang membangun semangat dan motivasi orang lain, e) menghindari kebiasaan debat tanpa konsep yang jelas, f) menghindari kebiasaan membenarkan diri sendiri dan tidak malu mengakui kesalahan dan meminta maaf, g) menghindari kebiasaan mengkritrik destruktif pada orang lain, h) membiasakan diri

\footnotetext{
${ }^{46}$ Husaini Usman, Manajemen..., 520-521.

${ }^{47}$ Husaini Usman, Manajemen..., 521.
}

Dirasah, Vol. 3, No. 1, Februari 2020 
menjadikan orang lain sebagai orang penting, i) membiasakan membicarakan hal-hal yang diminati orang lain, j) membiasakan menghormati pendapat orang lain. ${ }^{48}$

\section{Analisis}

Kinerja dalam konteks organisasi pada dasarnya merupakan bagian-bagian kecil dari proses tercapainya tujuan organisasi. Sebagaimana disampaikan terdahulu bahwa kinerja dalam organisasi, baik kinerja secara individual maupun tim, dipengaruhi oleh factor; kemampuan dan keahlian, pengetahuan akan pekerjaan, rancangan pekerjaan, kepribadian, motivasi, kepemimpinan, budaya organisasi, kepuasan, loyatilas, disiplin, komitmen dan lingkungan kerja. ${ }^{49} \mathrm{Hal}$ ini mengisyaratkan bahwa proses pencapaian visi, misi dan tujuan organisasi pendidikan dipengaruhi oleh berbagai factor tersebut. Maka dalam hal ini, baik pemimpin maupun anggota organisasi lainnya, harus memastikan bahwa semua factor tersebut bersifat kondusif untuk pencapaian tujuan.

Organisasi pendidikan, sebagai sebuah perkumpulan orang (sumber daya manusia) selalu bersifat homogeny, baik dari segi kemampuan (skill), kepribadian, motivasi, komitmen dan berbagai penyikapan terhadap factor-faktor yang mempengaruhi kinerja tersebut. Dalam konsep Hersey \& Blancard (dalam Pasolong), tingkat kematangan bawahan (SDM) terbagi dalam empat kategori yang pada akhirnya akan menentukan gaya kepemimpinan, yaitu; a) bawahan dengan tingkat kematangan rendah, yaitu bawahan yang tidak mampu dan tidak mau memikul tanggung jawab dan melaksanakan tugas (model direktif), b) bawahan dengan tingkat kematangan rendah ke sedang, yaitu bawahan yang tidak mampu tetapi memiliki motivasi untuk memikul tanggung jawab, atau memiliki keyakinan tetapi kurang memiliki ketrampilan dan pengetahuan (model konsultatif), c) bawahan tingkat kematangan dari sedang ke tinggi, yaitu memiliki kemampuan tetapi tidak memiliki motivasi untuk melakukan tugas yang diberikan (model partisipatif), d) bawahan tingkat kematangan tinggi, yaitu mampu dan mau memikul tanggung jawab (model delegatif). ${ }^{50}$ Kemauan (motivasi) anggota organisasi sebagaiman disampaikan terdahulu, dipengaruhi oleh berbagai factor, baik internal (dari dalam diri) maupun eksternal (dari luar pribadi).

\footnotetext{
${ }^{48}$ Husaini Usman..., 522.

${ }^{49}$ Kasmir, Manajemen Sumber Daya Manusia (Teori dan Praktik), (Jakarta; Raja Wali, Jakarta, 2016), 189

${ }^{50}$ Pasolong, Kepemimpinan Birokrasi.., 50
}

Dirasah, Vol. 3, No. 1, Februari 2020 
Berdasar paparan di atas dapat disimpulkan bahwa ketrampilan atau pengetahuan, dan kemauan secara bersama-sama merupakan factor penentu kinerja individu maupun tim dalam organisasi pendidikan. Hal ini menuntut adanya kemampuan pemimpin dan anggota organisasi dalam mengelola (to manage) ketrampilan interpersonal masing-masing sehingga menjadi identitas organisasi (iklim organisasi, budaya organisasi) yang kondusif.

Dalam konteks Islam, setiap individu adalah pemimpin, Hadist Riwayat Bukhari dan Muslim, Rasulullah Saw bersabda;

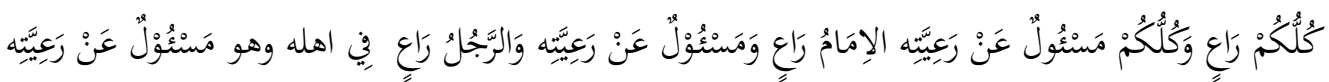

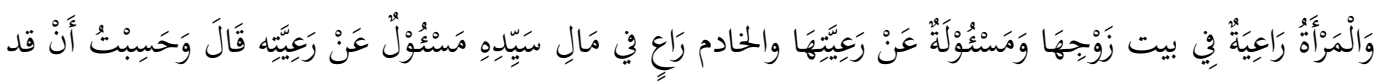

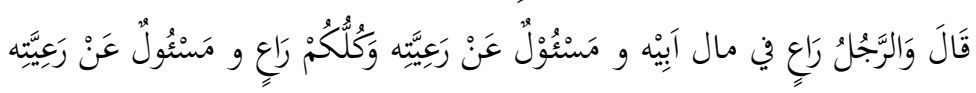

Artinya : Кати sетиa adalah pemimpin dan dimintai pertanggung jawabannya, pemerintah harus bertanggung jawab terhadap rakyatnya. Suami adalah pemimpin keluarganya dan wajib bertanggung jawab atas keluarga yang dipimpinnya. Istri adalah pemimpin rumah tangga dari suami dan anakanaknya, ia wajib bertanggung jawab terhadap mereka. Seorang hamba adalah penjaga harta tuannya, ia wajib bertanggung jawab atas harta yang dijaga. Ingatlah, kamu semua adalah pemimpin dan akan bertanggung jawab terhadap kepemimpinan tersebut. (Muttafaq Alaih). ${ }^{51}$

Hadist ini menegaskan bahwa setiap individu, baik secara personal maupun organisatoris adalah pemimpin dan harus mempertanggung jawabkan kepemimpinannya. Hal ini mengisyaratkan bahwa setiap individu tersebut harus memiliki ketrampilan sebagai pemimpin dan menjalankan fungsi-fungsi dan peran kepemimpinannya seperti peran sebagai motivator, konselor maupun advisor. Dan untuk menjalankan fungsi dan peran tersebut secara efektif, dituntut memiliki ketrampilan interpersonal.

Permasalah tingkat penguasaan ketrampilan atau pengetahuan misalnya, dalam konsep manajemen sumber daya manusia solusi yang diambil adalah pelatihan dan pembinaan. Dalam konsep manajemen interpersonal dapat disiasati dengan berbagi pengetahuan. Berbagi pengetahuan dalam organisasi, menurut Nonaka dan Takeuchi (dalam Heli dan Arisudana) merupakan pengetahuan di mana pengetahuan yang dimiliki karyawan sebagai individu diinternalisasikan ke

51 Ahmad Mudjab Mahalli \& Ahmad Rodhi Hasbullah, Hadis-Hadis Muttafaq „Alaih : Bagian Munakahat \& Mu"amalat, Cet I, Jakarta: Kencana, 2004. 254.

Dirasah, Vol. 3, No. 1, Februari 2020 
dalam dasar pengetahuan organisasi. Pengetahuan diciptakan melalui interaksi antar individual pada berbagai level dalam organisasi. ${ }^{52}$ Tanpa adanya iklim berbagi pengetahuan (ketrampilan) yang kondusif bisa berdampak dapat ketegangan, kesenjangan ketrampilan dan kesenjangan prestasi yang akan berdampak langsung pada kelangsungan organisasi. Artinya, dengan manajemen interpersonal yang kondusif, permasalahan penguasaan atas ketrampilan kerja pada dasarnya dapat diselesaikan dalam organ organisasi itu sendiri. Demikian halnya dengan seluruh factor yang mempengaruhi kinerja, termasuk motivasi.

\section{Kesimpulan}

Manajemen, manajemen sumber daya manusia pada dasarnya merupakan penerapan fungsi-fungsi manajemen dalam konteks pengelolaan sumber daya manusia, meliputi fungsi; perencanaan, pengadaan sumberdaya manusia, pembinaan dan pengembangan, promosi, kompensasi dan evaluasi. Sumber daya manusia dalam setiap organisasi memiliki 4 karakter mendasar, yaitu; a) tingkat kematangan rendah; tidak mampu dan tidak mau memikul tanggung jawab dan melaksanakan tugas, b) tingkat kematangan rendah ke sedang; tidak mampu tetapi memiliki motivasi untuk memikul tanggung jawab, atau memiliki keyakinan tetapi kurang memiliki ketrampilan dan pengetahuan, c) tingkat kematangan dari sedang ke tinggi; memiliki kemampuan tetapi tidak memiliki motivasi untuk melakukan tugas yang diberikan, d) tingkat kematangan tinggi, yaitu mampu dan mau memikul tanggung jawab.

Motivasi merupakan serangkaian sikap dan nilai-nilai yang mempengaruhi individu untuk mencapai hal yang spesifik sesuai dengan tujuan individu. Sikap dan nilai tersebut merupakan sesuatu yang invisible yang memberikan kekuatan yang mendorong individu untuk bertingkah laku dalam mencapai tujuan. Terdapat beragam teori motivasi yang dikemukakan para ahli, seperti Teori Hirerki kebutuhan Abraham Maslow, Teori X dan Y Doughlas McGregor, Teori Higienis Frederick Herzberg, Teori tiga kebutuhan David McClelland, Teori penguatan (B.F. Skinner), Teori model karakteristik pekerjaan (JCM), Teori kesetaraan (J. Stacey Adams), Teori pengharapan (Victor Vrom), atau Teori gabungan (Robinson \& Coulter) dimana masing-masing memiliki konsep yang berbeda tentang motivasi dan upaya memotivasi. Namun pada intinya, factor yang mempengaruhi motivasi terbagi dalam dua jenis, yaitu motif internal dan motif eksternal.

\footnotetext{
52 Avin Fadilla Heli dan Iman Arisudana, Kepemimpinan Transformasional, Kepercayaan dan berbagi Pengetahuan dalam Organisasi, Jurnal Psikologi, Yogyakarta, UGM, vol 36 No 2 Desember 2009, 95-105.
}

Dirasah, Vol. 3, No. 1, Februari 2020 
Kinerja (performance) dapat diartikan sebagai hasil kerja yang dapat dicapai oleh seseorang atau sekelompok orang dalam organisasi, sesuai wewenang dan tanggung jawab masing-masing, dalam rangka mencapai tujuan organisasi bersangkuatan secara legal, tidak melanggar hukum dan sesuai dengan moral maupun etika. Kinerja dalam organisasi, baik kinerja secara individual maupun tim, dipengaruhi oleh factor; kemampuan dan keahlian, pengetahuan akan pekerjaan, rancangan pekerjaan, kepribadian, motivasi, kepemimpinan, budaya organisasi, kepuasan, loyatilas, disiplin, komitmen dan lingkungan kerja.

Keterampilan interpersonal adalah kemampuan bekerja secara efektif dengan orang lain, memperhatikan empati dan pengertian, memperhatikan motivasi dan tujuan mereka.Proses keterampilan interpersonal umumnya terdiri dari 4 hal, yaitu; a) Saling mengenal dan mempercayai, b) Saling berkomunikasi secara tepat dan jelas, c) Saling menerima dan mendukung, d) Menyelesaikan konflik dan masalah dalam berhubungan dengan orang lain secara konstruktif. Dalam konsep Islam, setiap individu, baik secara personal maupun organisatoris adalah pemimpin dan harus mempertanggung jawabkan kepemimpinannya. Hal ini mengisyaratkan bahwa setiap individu tersebut harus memiliki ketrampilan sebagai pemimpin dan menjalankan fungsi-fungsi dan peran kepemimpinannya seperti peran sebagai motivator, konselor maupun advisor. Dan untuk menjalankan fungsi dan peran tersebut secara efektif, dituntut memiliki ketrampilan interpersonal.

\section{Daftar Pustaka}

Abdurokhim Agus Riyadi, Pengaruh Motivasi Kerja Konsep Islami Terhadap Kinerja Pegawai, Amwaluna, Vol. 1 No.2 (Juli, 2017), 246-262

Achmad Patoni. Konsep Dasar Kepemimpinan Profetik Pendidikan Islam Tulungagung, IAIN Tulungagung. 2017.

Ahmad Mudjab Mahalli \& Ahmad Rodhi Hasbullah. Hadis-Hadis Muttafaq „,Alaih : Bagian Munakahat \& Mu"amalat, Cet I, Jakarta: Kencana. 2004.

Akif Khilmiyah, Perbandingan Keterampilan Intrapersonal Dan Interpersonal BerbasisPendidikan Karakter Siswa Sekolah Dasar Negeri Kasihan Bantul, UMY, Jurnal Ilmu-Ilmu Keislaman. 2013.

Ambar Teguh dan Rosidah. Manajemen Sumber Daya Manusia, Yogyakarta; Graha Ilmu. 2003.

Dirasah, Vol. 3, No. 1, Februari 2020 
Ary Gunawan. Administrasi Sekolah, Administrasi Pendidikan Mikro, Jakarta: Rineka Cipta. 1996.

Avin Fadilla Heli dan Iman Arisudana, Kepemimpinan Transformasional, Kepercayaan dan berbagi Pengetahuan dalam Organisasi, Jurnal Psikologi, Yogyakarta, UGM, vol 36 No 2 Desember 2009, 95-105.

DW. Johson. Reaching out : interpersonal effectiveness and self-actualization Englewood Cliffs, N.J: Prentice-Hall. 1972.

E. Mulyasa. Manajemen Berbasis Sekolah, Bandung: Remaja Rosda Karya. 2002. Fuad Mas'ud. Survai Diagnosis Organisasional (Konsep dan Aplikasi), Semarang; Badan Penerbit Universitas Diponegoro. 2014.

Gary Dessler. Manajemen Sumberdaya Manusia, edisi 10, Jakarta, Indeks. 2018. Husaini Usman. Manajemen; Teori Praktik dan Riset Pendidikan, Yogyakarta, Pustaka Pelajar. 2014.

Ivanchevich, John. M. Donelly Jr, James H. Gibson. Organisasi, Surabaya; Erlangga. 1995.

Kasmir. Manajemen Sumber Daya Manusia (Teori dan Praktik), Jakarta; Raja Wali. 2016.

Ngalim Purwanto dan Sutaadji Djojopranoto. Administrasi Pendidikan, Jakarta: Mutiara Sumber Widya. 1996.

Paull Hersey and Ken Blanchard. Majemen Perilaku Organisasi : Pendayagunaan Sumber Daya Manusia, terj. Jakarta: Erlangga. 1982.

Piet A. Sahertian. Dimensi-Dimensi Administrasi Pendidikan di Sekolah Surabaya, Usaha Nasional. 1994.

Prim Masrokan Mutohar. Manajemen Mutu Sekolah; Strategi Mutu Dan Daya Saing Lembaga Pendidikan Islam, cet 2, Yogyakarta, Ar-Ruzz Media. 2014.

Purnamie Titisari. Peranan Organizational Citizenship Behavior (OCB) Dalam Meningkatkan Kinerja Karyawan, Jakarta; Mitra Wacana Media. 2014.

Robbins P. Stepter,. Perilaku Organisasi, Jakarta: Gramedia. 2003. 
Stephen P Robbins \& Mary Coulter. Manajemen, edisi ke 8, Yogyakarta, Indeks. 2007.

Suryadi Prawirosentono. Kebijakan Kinerja Karyawan, Yogyakarta; BPFE. 1999.

Sutarno. Serba-serbi Manajemen Bisnis, Graha Ilmu, Yogyakarta. 2011.

Veithzal Rivai, Ella Jauvani Sagala. Managemen Sumber Daya Manusia untuk Perusahaan, Jakarta; Rajawali Pers. 2013.

Wahyusumidjo. Kepemimpinan Kepala Sekolah, Tinjauan Teoritik dan Permasalahan, Jakarta; Raja Grafindo Persada. 2002.

Zaini Muchtarom. Dasar-Dasar Manajemen Dakwa, Yogyakarta: Al-Amin Press. 1996.

Copyright (C) 2020 Journal Dirasah: Vol. 3, No. 1,Februari 2020, p-ISSN: 2615-0212, e-ISSN;

2621-2838

Copyright rests with the authors

Copyright of Jurnal Dirasah is the property of Jurnal Dirasah and its content may not be copied oremailed to multiple sites or posted to a listserv without the copyright holder's express writtenpermission. However, users may print, download, or email articles for individual use.

https://ejournal.iaifa.ac.id/index.php/dirasah

Dirasah, Vol. 3, No. 1, Februari 2020 